\title{
PE $28-3$
}

SUPPLAMIATARY RHPORT ON THE KOBUK COPPER PROSPECT, SHUNGNAK DISTRICT, ALASKA,

by

Bobert $H$, Saundero Agroclate Mind Eg Engineer 
The Kobuk copper prospect 1 o on Raby Crook, tributary to the Shungnak Rivar, in the gouthern part of the dimbler R1 rar quadrangle at $67^{\circ} 05^{\mathrm{r}} \mathrm{N}$ latitud and $156^{\circ} 55^{\circ} \mathrm{W}$ longt tud. The prospeot has boen described in two earlier Department of Mines reporte; they are: REPORT ON THE PREIMINABY RXAMINAIION OF THE GERG PBOSPICT, SHUNGNAR DISTRICT, ALASKA, 2953, end REPORT ON TEIE RXCMLATION OF THE KOBUK COPPER PROSPHCT, SHOMGHAK DISIRICT, SIASKA, 1955, both by Robort H. Squnders, ABsoclato Mining Singineer. Coptes of both of thase earlier reports aro on file at the Departient of Mines offloes at Juneau, Oolloge, and Nome.

The prospect vas examined asaln on September 30, and October 1. 1956, by Fobert I. Saundere, sosociate Minlag Fnglnoeri this report 1s written from notes taken during that examination, and 1t is interded to supplement the earlier reports. The 1956 - cemination was made primarily to investigato and Bamplo a radioactive zone that outs across the copper brobody. Ithi zone was uncovered by trenching durting the aummer 1956. At the time of the examination, all the exposires were coverea by about 61 aches of snow; water and silt had frozen In the bottomg of the trenches ao thet shoreling out the anow old not uncover tho bodrock. The orly Flatbie bedrock expoem ures werc on the sides of some of the trenches.

The radioactive zone is exposed on the Iron Cap clatm on a vertical rock sace at the oid of a bulboror cut about bofout 
1nglde the soitheast olde I1ne of the clatm and about 600 foet from the northeast ond line of the clatu. The zono is 3 to 6 feet wide; $1 \mathrm{t}$ is mado consplousus by a redalab-orown limont to coloration. The radioactive zone appears to strike about northeast-southweat. An attent was made to trace this zone to the southwegt by running a sorles of short traverges wh th a Nucliometer, but the zone could be traced for only about 30 foot in this menner, however, whet appoars to be the same gone 10 exposed in a trench about 300 foet to the southwest. It thus appears that the radiogotive zone continues for at loast 300 feet.

A diamond drill was moved onto the property in 1956, and orliling was started late in the roason. An AX bit was used, gnd core recovery was good. Hole No. 12 was drillod vertically on the Iron Cap clatm about 60 feet inslide the southeagt side Ine and about 590 foet from the northeast ond Ine. The hole wa bottomed at 240 feet. Hole No. 23 was started pout 80 feet northwest of Holo No. 12. It boars $579^{\circ} \mathrm{H}$ at minur $64^{\circ}$. When the hole had reached 63 fest, drilling for the season ras stopoed because of an early freeze. It is planned that this hole will be continued when crili1ag begins in 1957. There 18 copper minerallation in varylne amounts in neerly all the rock that bas boen oored. The corea from the drillng are bolng shtpped to the Gallgher Company of Salt Lake C1ty for evaluation of the deposit and dealgn of a mill. Two amples wer taken from the exposure of the radoactive 
zone durdar this exarination. They were aseryod for copper, gold, and silver at the Territorial Department of Mines assay office at College by Donald Steln, Assayer-Engtneer, and they were tested for uranium at the Territorial Depertment of Mues assay office at Ketchlkan by A. E. Glover, Assayer-Fuginoor. The regulta are shown in the followng tables

SARPILES FROM TRE KOBUK COPPFR PROSPECT

\begin{tabular}{|c|c|c|c|c|c|}
\hline Sample & & on & & Cont & \\
\hline No, & $\mathrm{Gol}$ & SILver & Copper & eI & $\mathrm{J}_{3} \mathrm{O}_{8}$ \\
\hline 50 & $T \mathbf{r}$ & 0.22 & 2.45 & 0.033 & Not Pur \\
\hline 51 & Ir & 0.08 & 1.32 & 0.276 & 0.065 . \\
\hline
\end{tabular}

The blgt degree of oxtiation of the material sompled suggests that urantum may have boen loached from the uppor part of the minerallzed zone. As work progreases on the maln orebody, this zone should be investigated in dopth to determine the uranium content of the uneltered material. 